University of Montana

ScholarWorks at University of Montana

Numerical Terradynamic Simulation Group

Publications

Numerical Terradynamic Simulation Group

$12-2004$

\title{
Satellite observations of annual variability in terrestrial carbon cycles and seasonal growing seasons at high northern latitudes
}

John S. Kimball

University of Montana - Missoula

Maosheng Zhao

Kyle C. McDonald

City College of New York

Faith Ann Heinsch

Steven W. Running

University of Montana - Missoula

Follow this and additional works at: https://scholarworks.umt.edu/ntsg_pubs

Let us know how access to this document benefits you.

\section{Recommended Citation}

Kimball, J.S., M. Zhao, K.C. McDonald, F.A. Heinsch, and S. Running, 2004. Satellite observations of annual variability in terrestrial carbon cycles and seasonal growing seasons at high northern latitudes. In Microwave Remote Sensing of the Atmosphere and Environment IV, G. Skofronick Jackson and S. Uratsuka (Eds.), Proceedings of SPIE - The International Society for Optical Engineering, 5654, 244-254.

This Conference Proceeding is brought to you for free and open access by the Numerical Terradynamic Simulation Group at ScholarWorks at University of Montana. It has been accepted for inclusion in Numerical Terradynamic Simulation Group Publications by an authorized administrator of ScholarWorks at University of Montana. For more information, please contact scholarworks@mso.umt.edu. 


\title{
Satellite observations of annual variability in terrestrial carbon cycles and seasonal growing seasons at high northern latitudes
}

\author{
John S. Kimball*a,c ${ }^{\mathrm{a}}$, Maosheng Zhao ${ }^{\mathrm{c}}$, Kyle C. McDonald ${ }^{\mathrm{b}}$, Faith Ann Heinsch ${ }^{\mathrm{c}}$, and Steve \\ Running ${ }^{\mathrm{c}}$ \\ ${ }^{a}$ The University of Montana Flathead Lake Biological Station, 311 Bio Station Lane, Polson, MT, \\ USA 59860-9659; \\ b Jet Propulsion Laboratory, California Institute of Technology, Pasadena, CA, USA 91109-8099; \\ ${ }^{c}$ NTSG, College of Forestry and Conservation, The University of Montana, Missoula, MT 59812
}

\begin{abstract}
Global satellite remote sensing records show evidence of recent vegetation greening and an advance in the onset of the growing season at high latitudes. We apply a terrestrial net primary production (NPP) model driven by satellite observations of vegetation properties and daily surface meteorology from an atmospheric GCM to assess spatial patterns, annual variability, and recent trends in vegetation productivity across Alaska and northwest Canada. We compare these results with regional observations of the timing of growing season onset derived from satellite passive microwave remote sensing measurements from the Special Sensor Microwave Imager, SSM/I. Our results show substantial variability in annual NPP for the region that appears to be driven largely by variations in canopy photosynthetic leaf area and average summer air temperatures. Variability in maximum canopy leaf area and NPP also correspond closely to remote sensing observations of the timing of the primary seasonal thaw event in spring. Relatively early spring thawing appears to enhance NPP, while delays in seasonal thawing and growing season onset reduce annual vegetation productivity. Our results indicate that advances in seasonal thawing and spring and summer warming for the region associated with global change are promoting a general increase in NPP.
\end{abstract}

Keywords: AVHRR, boreal, carbon cycle, climate change, NPP, arctic tundra, freeze/thaw, SSM/I

\section{INTRODUCTION}

Boreal forest and Arctic tundra biomes of the northern high $\left(>50^{\circ} \mathrm{N}\right)$ latitudes are undergoing significant change coinciding with recent and persistent climatic warming for the region. ${ }^{1,2}$ Recent evidence of change includes melting permafrost and deepening soil active layer depths ${ }^{3}$, advances in the timing and length of seasonal growing seasons ${ }^{4,5}$, increased vegetation growth and alteration of land-atmosphere exchanges of radiatively active gases. ${ }^{6-8}$ Net primary production (NPP) is the primary conduit of carbon transfer from the atmosphere to the land surface and is thus a fundamental component of the global carbon cycle. The NPP process involves plant sequestration of atmospheric $\mathrm{CO}_{2}$ through photosynthesis and carbon storage in vegetation biomass and soils. Long-term satellite and aerial remote sensing observations of a greening arctic indicate a regional response of increasing NPP for northern terrestrial temperate and high latitudes. ${ }^{4,8}$ Stand level observations and process modeling studies provide additional evidence of recent increases in NPP for boreal Alaska, Canada and the northern boreal tree line, coinciding with regional warming trends and associated lengthening of the growing season at high latitudes. ${ }^{10-11}$ However, other evidence from tree ring data indicates a negative boreal NPP response to a warming climate due to temperature-induced drought stress. ${ }^{12}$

Each spring approximately 50 million $\mathrm{km}^{2}$ of Earth's terrestrial northern hemisphere undergoes a seasonal transition from predominantly frozen to nonfrozen (i.e., thawed) conditions. ${ }^{13}$ These relatively abrupt seasonal transitions represent the closest analog to a biospheric on/off switch existing in nature, affecting surface meteorological conditions, ecological trace gas dynamics, energy exchange, and hydrologic activity profoundly. In seasonally frozen environments, the growing season is determined primarily by length of the nonfrozen period. Variations in both timing of spring thaw and the resulting growing season length have been found to have a major impact on terrestrial NPP and atmospheric $\mathrm{CO}_{2}$ source/sink strength in boreal regions. ${ }^{7,14}$ The timing of spring thaw in particular, can influence boreal carbon uptake dramatically through temperature and moisture controls to net photosynthesis and respiration processes. ${ }^{15-16}$ Regional analyses of annual NPP for boreal and subalpine evergreen forests of North America show a 
sensitivity to spring thaw timing on the order of $1 \%$ per day immediately following initiation of the growing season. ${ }^{17}$ Temporal variations in the onset of frozen conditions in the fall are also significant but generally have less impact on NPP due to the increased importance of other controls over vegetation photosynthetic activity such as photo-period length. ${ }^{17}$ Recent changes in the seasonal cycle of atmospheric $\mathrm{CO}_{2}$ at high northern latitudes have also been attributed to earlier ecosystem carbon uptake and increased NPP associated with earlier seasonal thawing and warmer springtime air temperatures. $5,7,18$

Satellite remote sensing at microwave wavelengths is sensitive to the predominant freeze/thaw state of the landscape and provides a mechanism for assessing spatial and temporal variability in the onset of the growing season and associated biophysical processes at high latitudes. ${ }^{5,17,19}$ Brightness temperature measurements obtained from the Special Sensor Microwave/Imager (SSM/I) have been applied in terrestrial cryosphere studies including snow cover extent mapping and frozen soils analyses. ${ }^{20,21}$ The SSM/I brightness temperature measurement record has also been used to examine recent trends in the timing of springtime thaw across the panboreal high latitudes from 1988-2001. ${ }^{5}$ Complementary global satellite remote sensing observations are also available from optical-infrared sensors such as the NOAA AVHRR that provide repeat monitoring capabilities, consistent sampling, and spatially contiguous spectral reflectance information that are sensitive to vegetation structure and photosynthetic biomass. This information has been used as a major driver of simple production efficiency models for spatial mapping and monitoring of gross primary productivity (GPP) and NPP across large regions. ${ }^{8,22-24}$

For this investigation, we applied a biome-specific production efficiency model driven by daily surface meteorological inputs from an atmospheric GCM and satellite remote sensing observations of vegetation structure from the NOAA AVHRR time series to assess spatial patterns and annual variability in NPP for Alaska and northwest Canada from 1988 to 2000 . We conducted a model sensitivity analysis to evaluate the primary mechanisms driving NPP variability. We also compared regional NPP anomalies with coincident satellite remote sensing observations of primary seasonal thawing from the SSM/I daily time series to assess relationships between growing season onset and annual vegetation productivity.

\section{METHODS}

\subsection{NPP calculations}

The domain for this investigation encompasses boreal forest and arctic tundra biomes of Alaska and northwest Canada (Figure 1). The region is defined in terms of nodes of the National Snow and Ice Data Center (NSIDC) north polar

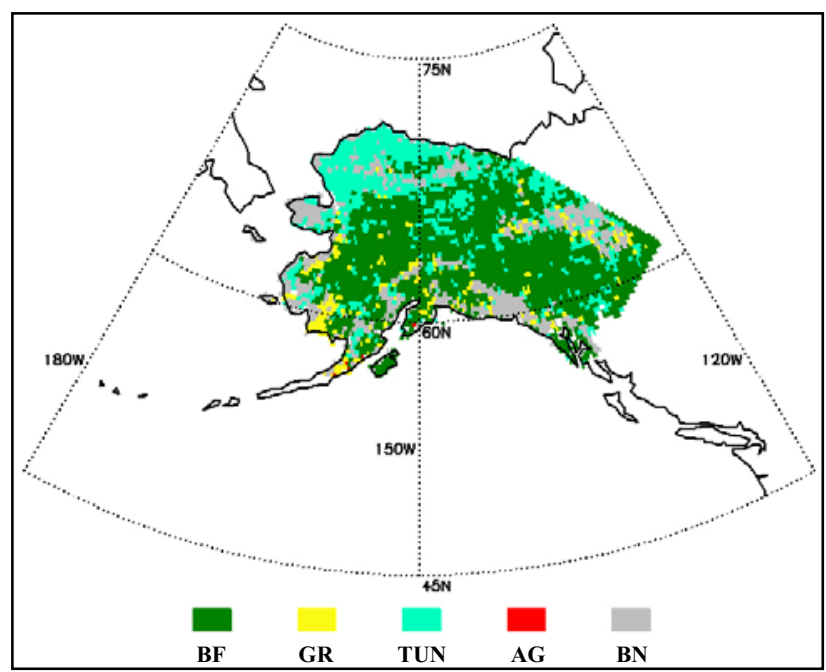

Figure 1. Alaska-Northwest Canada study region with major biomes representing boreal forest $(\mathrm{BF})$, Arctic tundra (TUN), grassland (GR), agricultural (AG) and barren (BN) classes defined from a NOAA AVHRR land cover classification; areas outside the studv region are shown in white. Equal-Area Scalable Earth (EASE) grid. ${ }^{20}$ The study domain spans a latitudinal range from $56.19^{\circ} \mathrm{N}$ to $71.24^{\circ} \mathrm{N}$, while land areas within the region comprise 3511 grid cells with nominal $25 \mathrm{~km} \times 25 \mathrm{~km}$ resolution and a total representative area of approximately 2.2 million $\mathrm{km}^{2}$. We used a NOAA AVHRR based global land cover classification to define major biomes within the study region. ${ }^{4,25}$ Boreal forest and tundra-grassland areas represented approximately $52 \%$ and $30 \%$ of the region, respectively, while agricultural systems represented less than $1 \%$ of the study domain. The rest of the study domain was composed of permanent ice and snow, barren land, and inland water bodies $(18 \%$ or $387,083 \mathrm{~km}^{2}$ ). These nonvegetated areas were masked from further analysis to isolate relationships between terrestrial vegetation productivity and environmental parameters.

A biome-specific Production Efficiency Model (PEM) was used to calculate GPP and NPP for unmasked pixels within the $25 \mathrm{~km}$ resolution EASE-grid domain. The PEM logic is described and verified in detail 
elsewhere, ${ }^{8,24,26}$ and summarized below. GPP $\left(\mathrm{g} \mathrm{C} \mathrm{m}^{-2}\right)$ was derived on a daily basis as:

$$
\begin{aligned}
& G P P=\varepsilon \bullet F P A R \bullet P A R \\
& \varepsilon=\varepsilon_{\max } \bullet T_{f} \bullet V P D_{f}
\end{aligned}
$$

where $\varepsilon$ is a light use efficiency parameter $\left(\mathrm{g} \mathrm{C} \mathrm{MJ}^{-1}\right)$ for the conversion of photosynthetically active radiation (PAR, $\mathrm{MJ} \mathrm{m}^{-2}$ ) to GPP, where PAR is assumed to represent $45 \%$ of incident solar radiation; FPAR is the fraction of absorbed PAR; $\varepsilon_{\max }$ is the potential maximum $\varepsilon$ under optimal conditions (i.e., no environmental stress); $T_{f}$ is a scalar that defines reductions in photosynthesis under low temperature conditions, while $V P D_{f}$ is a scalar that defines similar reductions under suboptimal surface air Vapor Pressure Deficit (VPD) and associated daytime water stress conditions. Both $T_{f}$ and $V P D_{f}$ are dimensionless parameters ranging from 1 for optimal conditions to 0 under complete canopy stomatal closure and minimal photosynthetic activity. Both $T_{f}$ and $V P D_{f}$ are defined from daily air temperature $\left(\mathrm{T}_{\min }\right)$ and VPD using simple photosynthetic response curves. These response curves and $\varepsilon_{\max }$ are prescribed for different biome types defined from the global land cover classification.

Net primary production $\left(\mathrm{g} \mathrm{C} \mathrm{m}^{-2}\right)$ is derived on an annual basis as the difference between the annual summation of daily net photosynthesis and autotrophic growth and maintenance respiration:

$$
\mathrm{NPP}=\sum_{1}^{365}\left(G P P-R_{m_{-} l r}\right)-\left(R_{m_{-} w}+R_{g}\right)
$$

where $R_{m_{-} l r}$ is the daily maintenance respiration of leaves and fine roots as derived from allometric relationships to canopy leaf-area index (LAI) and an exponential relationship between respiration and temperature. The $R_{m_{-} w}$ parameter represents the annual maintenance respiration from live wood, while $R_{g}$ represents the annual growth respiration; both $R_{m_{-} w}$ and $R_{g}$ are derived from allometric relationships between vegetation biomass and maximum annual LAI, and exponential respiration response curves to air temperature. The characteristic response curves for these calculations vary according to major biomes as defined by a Biome Properties Look-Up Table (BPLUT) and the global land cover classification. The BPLUT defines response characteristics for 11 major biomes including evergreen and deciduous needleleaf and broadleaf forests, mixed deciduous and evergreen forests, grasslands, shrublands, and croplands. The PEM used for this investigation is currently being used for operational global assessment and monitoring of GPP and NPP using LAI and FPAR data from the MODIS sensor onboard the NASA EOS Terra satellite from 2000 onward. $^{26,27}$ A detailed description of these algorithms and associated BPLUT properties can be found in the MODIS MOD17 User's Guide. ${ }^{28}$

For this investigation we applied the PEM described above to assess spatial and temporal variability in annual vegetation productivity for the study region over a 13-year period from 1988 to 2000. The PEM requires spatially explicit and temporally contiguous inputs of daily surface meteorology, LAI and FPAR, to derive GPP and NPP. Monthly LAI and FPAR data were obtained from the NOAA AVHRR Pathfinder dataset, which has an approximate 16 $\mathrm{km}^{2}$ spatial resolution and extends over the entire domain from 1982 to $2000 .^{4}$ These data were reprojected to the 25 $\mathrm{km}$ polar EASE-grid format using a nearest-neighbor resampling scheme. The LAI and FPAR data were then resampled to a daily time step by temporal linear interpolation of adjacent monthly values. Surface air temperature, incident solar radiation, and VPD inputs were provided by daily reanalysis data from the National Center for Environmental Prediction. ${ }^{29}$ The NCEP meteorological data are available globally in approximately 1.875 degree $(\sim 208 \mathrm{~km})$ spatial resolution and were reprojected into the $25 \mathrm{~km}$ resolution polar EASE-grid format using a biLagrange interpolation approach. ${ }^{30}$ PEM calculations were conducted for vegetated cells within the study region from 
1988 to 2000, and spatial patterns and annual variability in NPP were evaluated accordingly. We conducted a statistical correlation analysis to assess correspondence between annual productivity calculations, LAI, and mean annual surface meteorological parameters from the NCEP reanalysis. The statistical significance of these relationships was assessed at the $90 \%$ confidence level.

\subsection{Classification of primary seasonal thaw events}

The Special Sensor Microwave/Imager (SSM/I) is a multifrequency, linearly polarized passive microwave radiometer operating with a constant incidence angle of 53.1 degrees and has flown on the Defense Meteorological Satellite Program (DMSP) platform series. Coverage is global and began in August 1987. We utilized the 19 GHz horizontally polarized channel, which has a $70 \times 45 \mathrm{~km}$ footprint resolution. Data for this study were acquired as globally gridded brightness temperatures derived from orbital (swath) data. ${ }^{31}$ The SSM/I sensors have 6 AM and 6 PM equatorial crossing times for the ascending or descending orbital nodes, the crossing time and respective node depending on the platform in the DMSP series. Brightness temperature data corresponding to orbital passes with 6 PM equatorial crossing times were mapped to the $25 \mathrm{~km}$ resolution polar EASE-grid for each 24-hour period and used for temporal classification of primary thaw events. The data gridding scheme maximizes the radiometric integrity of the original brightness temperature values, maintains high spatial and temporal precision, and involves no averaging of original swath data. Daily SSM/I data, spanning winter 1988 through winter 2000, were assembled onto the $25 \mathrm{~km}$ EASE-grid grid covering the study domain. The daily composite data allow examination of annual thaw cycles from 1988-2000.

A material's radiometric brightness temperature, $\mathrm{T}_{\mathrm{B}}$, is characterized by its emissivity $e$, as $\mathrm{T}_{\mathrm{B}}=e \cdot \mathrm{T}$, where $\mathrm{T}$ is its physical temperature $\left({ }^{\circ} \mathrm{K}\right)$. Emissivity is a unitless variable ranging from 0 for a perfectly non-emitting material, to 1 for a perfect emitter (blackbody). ${ }^{32}$ Emissivity is a function of the material's dielectric constant and is directly sensitive to the phase (solid/liquid) of water within the media. As water changes from a solid to a liquid phase, its dielectric constant increases dramatically and significant increases in $e$ and $\mathrm{T}_{\mathrm{B}}$ result. Defining freeze/thaw as the predominant state (solid or liquid) of water within the landscape, we utilize the temporal change in $\mathrm{T}_{\mathrm{B}}$ associated with the primary landscape springtime thaw event to monitor the timing of thaw across the study domain.

Previous studies have employed thresholding schemes based on time-series signal processing to examine springtime thaw transitions with high temporal repeat microwave remote sensing data. ${ }^{14,17,19}$ These algorithms characterize landscape thaw transition sequences utilizing the response of time series radar backscatter resulting from large changes in the bulk landscape dielectric constant occurring as the landscape thaws. As $\mathrm{T}_{\mathrm{B}}$ responds similarly to the landscape dielectric constant, these approaches are also suitable for analysis of time-series brightness temperature.

We employed a step-edge detection scheme to identify the predominant springtime thaw transition event on an annual basis. In boreal regions, this event has been found to be generally coincident with the arrival of maximum surface wetness in spring associated with rising air temperatures, seasonal snowmelt, soil active layer thawing, and growing season onset. ${ }^{17}$ The technique is based on the application of an optimal edge detector for determining edge transitions in noisy signals. ${ }^{33}$ The time of primary springtime thaw event is determined from the convolution applied to $\mathrm{T}_{\mathrm{B}}$ :

$$
C N V(t)=\int_{-\infty}^{\infty} f^{\prime}(x) T_{B}(t-x) d x
$$

where $f^{\prime}(x)$ is the first derivative of a normal (Gaussian) distribution. The occurrence of the primary springtime thaw event is then given by the time, $t_{p}$, when $C N V(t)$ is a maximum. As the winter-spring transition progresses, the landscape may thaw and refreeze repeatedly. This technique accounts for the occurrence of weak edges, or less pronounced thaw events, as well as strong edges, and is less likely to classify minor thaw occurrences as the primary thaw event. This approach has been previously employed to examine thaw trends across the pan-Arctic basin and Alaska. ${ }^{5}$ For this investigation, we apply a similar approach to map the primary spring thaw event on an annual basis for each $25 \mathrm{~km}$ grid cell within the study domain.

The thaw classification algorithm (Eq. 4) was applied to each annual time series of SSM/I brightness temperature from 1988 to 2000, producing yearly maps of the primary spring thaw event across the study domain. Areas of permanent 
ice and snow, bare ground, and sparse vegetation cover were identified using the NOAA AVHRR based global land cover classification $^{4,25}$ and masked from further analysis to isolate the relationship between seasonal thawing and NPP. Annual anomalies of PEM- and SSM/Ibased results were calculated relative to long-term means or linear least-squares regression results, where significant $(\mathrm{P} \leq 0.1)$ secular trends were observed.

\section{RESULTS}

Satellite derived NPP results for the study domain are summarized in Table 1, while a map of mean annual NPP for the 1988-2000 period is presented in Figure 2. Mean annual NPP for the region is approximately $288+/-105.6$ [s] g C m${ }^{-2}$

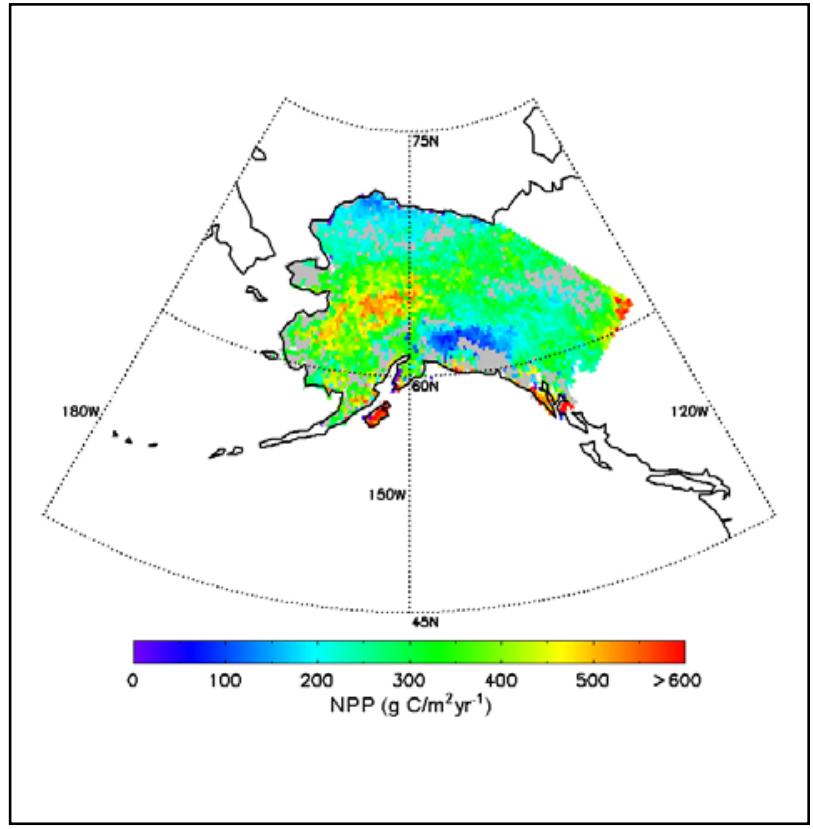

Figure 2. PEM predictions of mean annual NPP for the 1988-2000 time period. Barren land and other nonvegetated surfaces excluded from the analysis are shown in gray, while areas outside the study region are shown in white.

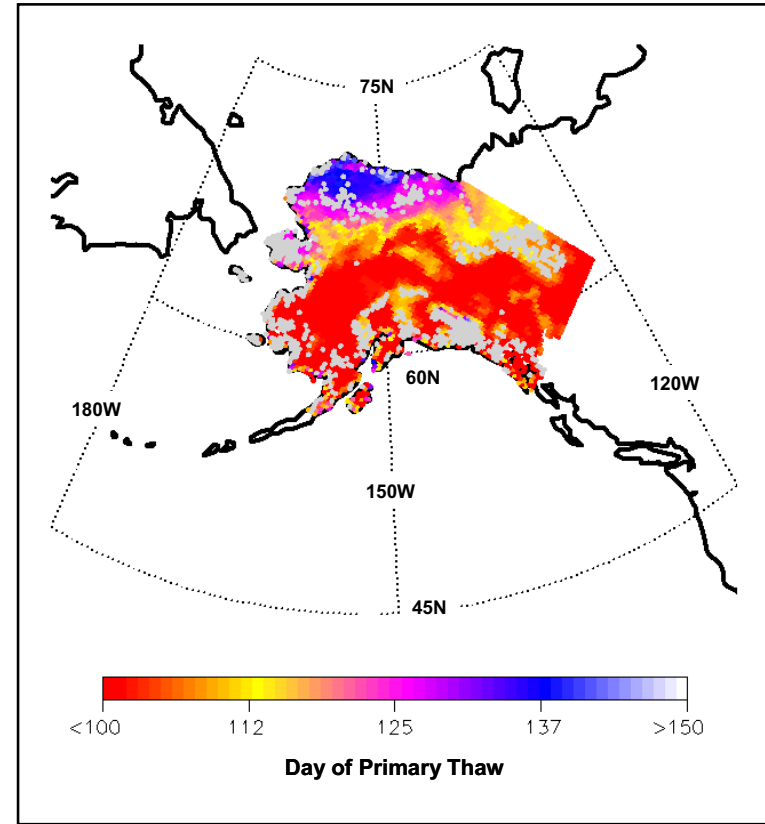

Figure 3. Mean annual timing of primary seasonal thaw events for the 1988-2000 period as derived from temporal classification of daily, descending orbit (6 PM local overpass), $19 \mathrm{GHz}$ brightness temperature data from the SSM/I sensor series. Barren land and other nonvegetated surfaces were excluded from the analysis and are shown in gray, while areas outside the study region are shown in white.

Table 1. Summary of NPP and primary thaw event results for the vegetated study domain.

\begin{tabular}{|l|l|c|c|}
\hline $\begin{array}{l}\text { Classification } \\
\text { Region }\end{array}$ & ${ }^{1}$ Area (\%) & $\begin{array}{l}{ }^{2} \mathrm{NPP}_{\mathrm{av}} \\
\left(\mathrm{g} \mathrm{C} \mathrm{m}^{-2} \mathrm{yr}^{-1}\right)\end{array}$ & $\begin{array}{l}{ }^{3} \text { Thaw date } \\
(\mathrm{DOY})\end{array}$ \\
\hline Entire domain & 100.0 & $288.0(105.6)$ & $106(20)$ \\
\hline Boreal forest & 52.0 & $320.0(112.4)$ & $102(19)$ \\
\hline Arctic tundra-grassland & 30.0 & $232.6(60.7)$ & $114(21)$ \\
\hline Agricultural & 0.1 & $168.5(51.0)$ & $110(37)$ \\
\hline
\end{tabular}

${ }^{1}$ Proportional area represented within the 2.2 million $\mathrm{km}^{2}$ study domain;

2 Mean annual NPP (standard deviations in parentheses) for 1988-2000 period;

${ }^{3}$ Mean annual spring thaw date (standard deviations in parentheses) for 1988-2000 period. 
$\mathrm{yr}^{-1}$, with substantial spatial and temporal variability. Spatial variability in annual productivity generally follows major physiographic, climatologic, and associated land cover gradients. Annual productivity is generally greatest within subarctic boreal evergreen coniferous and mixed deciduous-evergreen forests of the Yukon and central and southern Alaska. Annual productivity is generally lower at higher elevations of the Alaska and Brooks Ranges, and within polar tundra and grassland areas of northern Alaska and the Yukon. Boreal forests cover approximately 52\% $\left(1.16 \times 10^{6}\right.$ $\mathrm{km}^{2}$ ) of the study area and account for $41 \%$ of the total average annual NPP for the region, while Arctic tundra and grasslands represent $30 \%\left(661,056 \mathrm{~km}^{2}\right)$ of the region and $71 \%$ of total NPP. Agricultural biomes are the least productive on a unit area basis, and represent less than $1 \%$ of aerial coverage and total productivity for the region.

A map of the average timing of primary spring thaw events for the study region as derived from temporal classification of daily SSM/I brightness temperature observations for the 1988-2000 period is presented in Figure 3 and summarized in Table 1. The average timing of primary spring thawing extends over a 12 week period from approximately March $7^{\text {th }}$ (Day 66) to May $26^{\text {th }}$ (Day 146), with generally earlier occurrence at lower latitudes and elevations. The spatial pattern of spring thaw timing also shows general distinctions among the major land cover classes (Figure 1). Boreal forests show the earliest average arrival of seasonal thawing on approximately April 12 (Day 102), followed by agricultural and tundra-grassland areas with respective thaw dates of April $20^{\text {th }}$ (Day 110) and April $24^{\text {th }}$ (Day 114). However, land cover class coefficients of variation in seasonal thaw timing range from 18 to 34 percent, with considerable overlap among regional biomes.

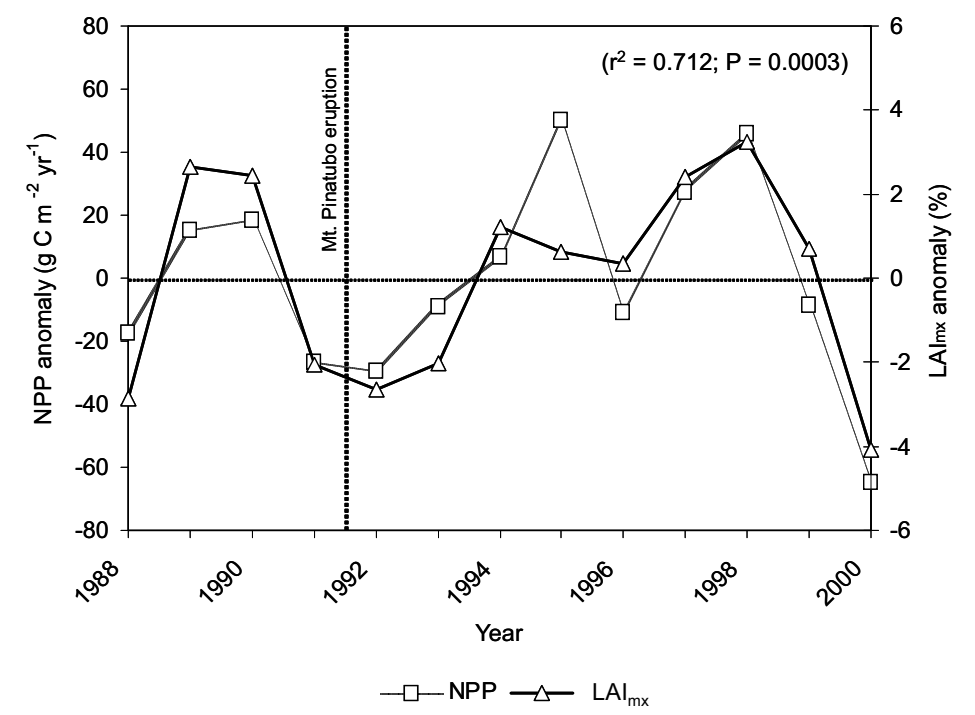

Figure 4. Annual variability and associated correspondence between PEM-based NPP and NOAA AVHRR Pathfinder observations of maximum annual LAI $\left(\mathrm{LAI}_{\mathrm{mx}}\right)$. The timeseries data are expressed as annual anomalies of regional averages for the entire vegetated study region, where variability in $\mathrm{LAI}_{\mathrm{mx}}$ is expressed as a proportion (\%) of long-term (1988-2000) average conditions; positive and negative anomalies denote respective increases and decreases in annual magnitudes relative to long-term average conditions. Approximate timing of the Mt. Pinatubo eruption is represented by a dashed, vertical line.

Temporal variability in NPP for the region coincided with changes in both vegetation structure and climatology. Annual variations in photosynthetic canopy structure inferred from NOAA AVHRR derived measures of maximum annual LAI $\left(\mathrm{LAI}_{\mathrm{mx}}\right)$ accounted for $71.2 \%(\mathrm{P}=0.0003)$ of the variability in annual NPP for the region as shown in Figure 4. Absolute annual variability in $\mathrm{LAI}_{\mathrm{mx}}$ and NPP was approximately $2.2 \%$ and $5.9 \%$, respectively. Years with relatively high NPP rates coincided with greater photosynthetic canopy cover, while lower productivity years coincided with reduced canopy cover. Annual NPP anomalies also corresponded directly to average summer air temperatures ( $\mathrm{r}$ $=0.718 ; \mathrm{P}=0.006$ ) indicating warmer temperatures during the growing season promote greater NPP by enhancing photosynthesis relative to autotrophic respiraton processes. No significant relationship was found, however, between NPP and mean annual air temperature because temperatures outside the growing season, which are reflected in mean annual values, have little direct impact on NPP since boreal-arctic ecosystems are largely dormant during these periods. Annual NPP in 1992 was approximately 9.4\% below long-term regional conditions and coincided with an approximate 2-year regional cooling event following the June 1991 volcanic eruption of Mt. Pinatubo (Figure 4). Previous studies have also documented the apparent short-term effects of the Pinatubo eruption on LAI, NPP, and atmospheric $\mathrm{CO}_{2}$ concentrations at high latitudes. ${ }^{8,34}$ A large positive NPP anomaly in 1998 coincided with relatively warm spring and 
early summer conditions, while the large negative NPP anomaly in 2000 coincided with relatively cool $\left(3-4{ }^{\circ} \mathrm{C}\right.$ below mean, 1992-2000, summer conditions) summer temperatures across Canada and Alaska (IPCC 2001).

Mean annual NPP for the region was inversely proportional to the timing of primary seasonal thawing in spring as derived from SSM/I based remote sensing (see Figure 5). The timing of the primary spring thaw event was inversely
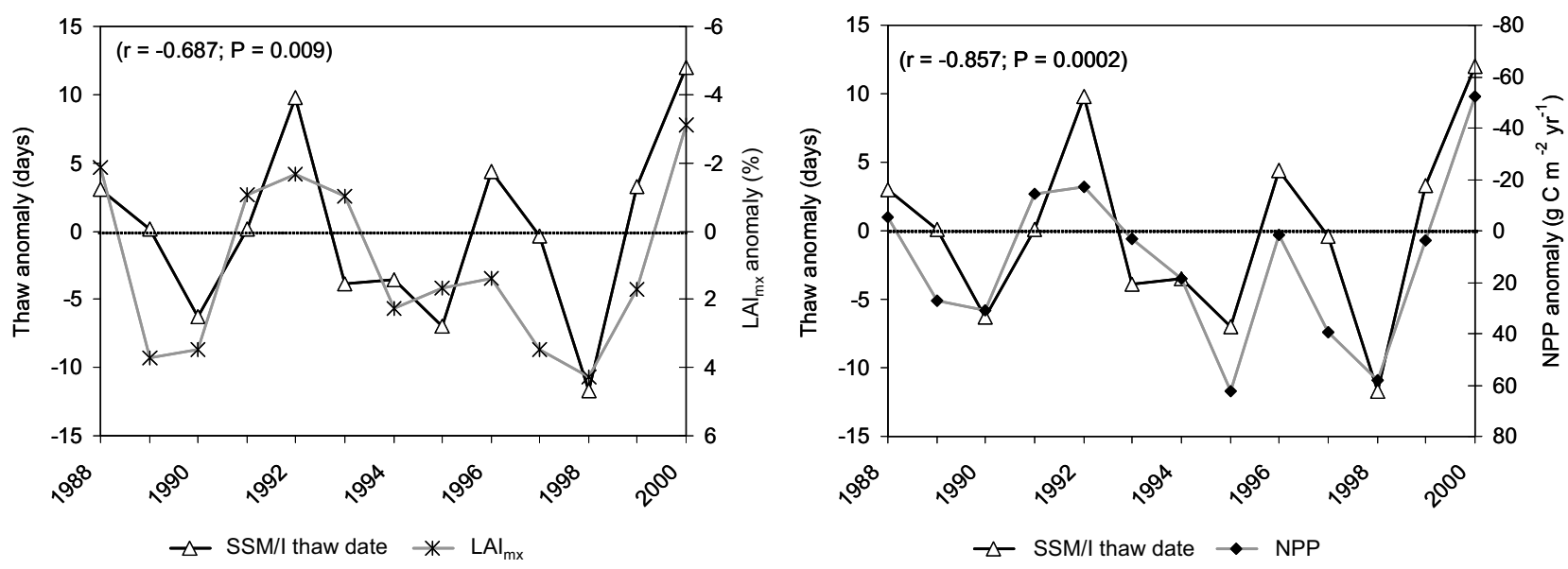

Figure 5. Annual variability and associated correspondence between SSM/I based seasonal thaw anomalies, and NOAA AVHRR based annual maximum mean monthly LAI (LAI $\mathrm{mx}_{\mathrm{m}}$; left) and PEM based NPP anomalies (right) for vegetated land cover within the Alaska-Northwest Canada study region. Positive and negative anomalies denote respective increases (advances) and decreases (delays) in annual values relative to long-term (1988-2000) average conditions.

proportional to both $\mathrm{LAI}_{\mathrm{mx}}(\mathrm{r}=-0.687 ; \mathrm{P}=0.009)$ and $\mathrm{NPP}(\mathrm{r}=-0.857 ; \mathrm{P}=0.0001)$ anomalies for the study domain. Years with relatively early seasonal thawing showed generally greater annual productivity and associated increases in photosynthetic biomass, while years with delayed seasonal thawing showed lower annual productivity rates and associated reductions in canopy cover. These results are consistent with other regional studies showing strong linkages between the timing of seasonal thawing, growing season onset, and annual vegetation productivity in boreal landscapes. ${ }^{4,15,17}$ At high $\left(>50^{\circ} \mathrm{N}\right)$ northern latitudes, cold temperatures and limited photoperiod largely constrain the growing season to a relatively brief period during the spring and summer months. These conditions contrast with temperate latitudes where growing seasons begin earlier and can extend well into the fall. ${ }^{8}$ In the spring, solar irradiance in boreal and Arctic regions is near the seasonal maximum, and photosynthesis and NPP proceed at relatively high rates following spring thawing and the arrival of warmer air temperatures. ${ }^{17,37}$ Boreal evergreen forests can accumulate as much as $1 \%$ of their annual NPP on a daily basis immediately following seasonal thawing in the spring, while potential accumulation rates are substantially reduced by decreasing photoperiod during later stages of the growing season. Thus year-to-year changes in the timing of growing season onset, indicated by satellite remote sensing observations of landscape freeze/thaw status, have a significant impact on annual NPP and vegetation biomass for the region.

\section{CONCLUSIONS}

The results of this study indicate that satellite optical-infrared remote sensing of annual variability in terrestrial NPP and photosynthetic biomass at high latitudes is inversely proportional to the timing of growing season onset inferred from satellite microwave remote sensing of landscape freeze/thaw status. Annual NPP calculations also corresponded directly with mean summer air temperatures for the region. Years with relatively warm summers and early seasonal onset of the growing season appear to promote greater net photosynthesis relative to autotrophic respiration, resulting in greater NPP; alternatively, relatively cool summers or delayed onset of the growing season promote the opposite response. These results differ somewhat from studies of Alaska White spruce forest stands that show evidence of a negative NPP response to warmer temperatures due to temperature-induced drought stress. ${ }^{12}$ Other studies show evidence of a generally positive NPP response to early growing season onset, but with variable sensitivity depending 
upon species composition and location. ${ }^{38}$ Still other studies indicate that NPP at high latitudes is predominantly cold temperature limited and responds positively to warmer air temperatures and earlier onset of the growing season. ${ }^{4,8,10,15}$ The results of this study imply that while surface air temperature records show a relatively consistent global warming trend since the early 1980s, NPP for boreal forest and arctic tundra of Alaska and Northwest Canada appears to be largely benefiting from regional warming and associated lengthening of annual growing seasons, particularly during the initial period following seasonal thawing when solar radiation levels are near seasonal maxima and plant available moisture is relatively abundant. However, our results also indicate that vegetation productivity is spatially and temporally complex for the region with the potential for a variable NPP response to projected warming.

For this investigation, we utilized daily meteorological inputs from an atmospheric General Circulation Model (GCM), satellite optical-infrared remote sensing measures of vegetation parameters, and general assumptions of plant physiological responses to environmental forcings to simulate regional patterns and annual variability in NPP for Alaska and northwest Canada. The land cover information used for this study and the resulting NPP calculations largely reflect dominant, overstory vegetation and do not explicitly account for mixed or subdominant vegetation categories within individual land cover classes. The accuracy of coarse resolution GCM meteorological data is also uncertain at high latitudes where regional monitoring networks useful for GCM calibration and reanalysis are extremely sparse and largely confined to coastal areas and lower elevations. Satellite monitoring of high latitude regions from optical-infrared remote sensing is also problematic due to poor solar illumination and image degradation from frequent cloud cover and other atmospheric aerosols, while observational trends from the long-term NOAA AVHRR record are uncertain because of issues related to navigational drift and cross-calibration of instrument series. All of these factors have the potential to adversely impact the relative accuracy of satellite based NPP calculations for the region. Nevertheless, the results of this study are consistent with a growing body of evidence indicating a generally positive boreal-arctic vegetation productivity response to the relaxation of low temperature constraints to photosynthesis from regional warming and earlier growing season onset. Our findings also indicate the recent trend of global change related warming at high latitudes is enhancing vegetation growth and sequestration of atmospheric $\mathrm{CO}_{2}$ in boreal and arctic ecosystems. However, while NPP may be enhanced under warmer conditions and longer growing seasons, the apparent effects of these changes on terrestrial carbon losses from soil respiration, fire and insect defoliations, and other regional disturbances are uncertain.

\section{ACKNOWLEDGEMENTS}

NOAA/NASA Pathfinder SSM/I Level 3 EASE-Grid brightness temperatures were obtained from the EOSDIS NSIDC Distributed Active Archive Center (NSIDC DAAC) at the University of Colorado, Boulder. This work was supported by grants from the National Science Foundation Office of Polar Programs and from the National Aeronautics and Space Administration (NASA) Office of Earth Science Enterprise. Portions of the research described in this paper were carried out at the Jet Propulsion Laboratory, California Institute of Technology, under contract with the National Aeronautics and Space Administration.

\section{REFERENCES}

1. M. C. Serreze, J. E. Walsh, F. S. Chapin III, T. Osterkamp, M. Dyurgerov, V. Romanovsky, W. C. Oechel, J. Morison, T. Zhang, and R. G. Barry, "Observational evidence of recent change in the northern high latitude environment," Climate Change, 46, 159-207, 2000.

2. J. D. Comisco, "Warming trends in the Arctic from clear sky satellite observations," Journal of Climate, 16, 3498$3510,2003$.

3. C. Oelke, T. Zhang, and M. C. Serreze, "Modeling evidence for recent warming of the Arctic soil thermal regime," Geophysical Research Letters, 31, L07208, doi:10.1029/2003GL019300, 2004.

4. R. B. Myneni, R.B., R. R. Nemani, and S. W. Running, "Estimation of global leaf area index and absorped par using radiative transfer models," IEEE Transactions on Geoscience and Remote Sensing, 35, 1380-1393, 1997. 
5. K. C. McDonald, J. S. Kimball, E. Njoku, R. Zimmermann, and M. Zhao, "Variability in springtime thaw in the terrestrial high latitudes: Monitoring a major control on the biospheric assimilation of atmospheric $\mathrm{CO}_{2}$ with spaceborne microwave remote sensing," Earth Interactions, (In press), 2004.

6. W. C. Oechel, G. L. Vourlitis, S. J. Hastings, and S. J. Bocharev, "Change in arctic $\mathrm{CO}_{2}$ flux over two decades: Effects of climate change at Barrow, Alaska, Ecological Applications, 5, 846-855, 1995.

7. J. T. Randerson, C. B. Field, I. Y. Fung, and P. P. Tans, "Increases in early season ecosystem uptake explain recent changes in the seasonal cycle of atmospheric $\mathrm{CO}_{2}$ at high northern latitudes," Geophysical Research Letters, 26, $2765-2768,1999$.

8. R. R. Nemani, C. D. Keeling, H. Hashimoto, W. M. Jolly, S. C. Piper, C. J. Tucker, R. B. Myneni, S. W. Running, "Climate-driven increases in global terrestrial net primary production from 1982 to 1999," Science, 300, 1560$1563,2003$.

9. M. Sturm, C. Racine, and K. Tape, "Increasing shrub abundance in the Arctic," Nature, 411, 546-547, 2001.

10. D'Arrigo, R.D. and G.C. Jacoby, "Tree growth-climate relationships at the northern boreal forest treeline of North America: evaluation of potential response to increasing carbon dioxide," Global Biogeochemical Cycles, 7, 525$535,1993$.

11. A. R. Keyser, J. S. Kimball, R. R. Nemani, and S. W. Running, "Simulating the effects of climate change on the carbon balance of North American high latitude forests," Global Change Biology, 6, 185-195, 2000.

12. V. Barber, G. P. Juday, and B. P. Finney, "Reduced growth of Alaskan white spruce in the twentieth century from temperature-induced drought stress," Nature, 405, $668-673,2000$.

13. D. A. Robinson, K. F. Dewey, and R. R. Heim, "Global snow cover monitoring: An update," Bulletin of the American Meteorological Society, 74, 1689-1696, 1993.

14. S. Frolking, M. L. Goulden, S. C. Wofsy, S. M. Fan, D. J. Sutton, J. W. Munger, A. M. Bazzaz, B. C. Daube, P. M. Crill, J. D. Aber, L. E. Band, X. Wang, K. Savage, T. Moore, and R. C. Harriss, "Modeling temporal variability in the carbon balance of a spruce/moss boreal forest," Global Change Biology, 2, 343-366, 1996.

15. P. Jarvis and S. Linder, "Constraints to growth of boreal forests," Nature, 405, 904-905, 2000.

16. S. Tanja, F. Berninger, T. Vesala, T. Markkanen, P. Hari, A. Mäkelä, H. Ilvesniemi, H. Hänninen, E. Nikinmaa, T. Huttula, T. Laurila, M. Aurela, A. Grelle, A. Lindroth, A. Arneth, O. Shibistova, and J. Lloyd, "Air temperature triggers the commencement of evergreen boreal forest photosynthesis in spring," Global Change Biology, 9, $1410-1426,2003$

17. J. S. Kimball, K. C. McDonald, S. W. Running, and S. Frolking, "Satellite radar remote sensing of seasonal growing seasons for boreal and subalpine evergreen forests," Remote Sensing of Environment, 90, 243-258, 2004.

18. C. D. Keeling, J. F. S. Chin, and T. P. Whorf, "Increased activity of northern vegetation inferred from atmospheric $\mathrm{CO}_{2}$ measurements," Nature, 382, 146-149, 1996.

19. J. S. Kimball, K. C. McDonald, A. R. Keyser, S. Frolking S., and S. W. Running S. W., "Application of the NASA Scatterometer (NSCAT) for classifying the daily frozen and non-frozen landscape of Alaska," Remote Sensing of Environment, 75, 113-126, 2001.

20. R. L. Armstrong and M. J. Brodzik, "An Earth-gridded SSM/I data set for cryospheric studies and global change monitoring," Advances in Space Research, 16, 155-163, 1995. 
21. T. Zhang and R. L. Armstrong, "Soil freeze/thaw cycles over snow-free land detected by passive microwave remote sensing," Geophysical Research Letters, 28, 763-766, 2001.

22. S. D. Prince and S. N. Goward, "Global primary production: A remote sensing approach," Journal of Biogeography, 22, 815-835, 1995.

23. C. S. Potter, S. Klooster, and V. Brooks, "Interannual variability in terrestrial net primary production: Exploration of trends and controls on regional to global scales," Ecosystems, 2, 36-48, 1999.

24. S. W. Running, P. E. Thornton, R. Nemani, and J. M. Glassy, "Global terrestrial gross and net primary productivity from the Earth Observing System, Methods in Ecosystem Science, O. Sala, R. Jackson, and H. Mooney, editors, pp. 44-57, Springer-Verlag, New York, 2000.

25. R. S. DeFries, M. Hansen, J. R. G. Townshend, and R. Sohlberg, R., "Global land cover classifications at 8 km spatial resolution: the use of training data derived from Landsat imagery in decision tree classifiers," International Journal of Remote Sensing, 19, 3141-3168, 1998.

26. S. W. Running, R. R. Nemani, F. A. Heinsch, M. Zhao, M. Reeves, and H. Hashimoto, "A continuous satellitederived measure of global terrestrial primary production," Bioscience, 54, 547-560, 2004.

27. M. Zhao, F. A. Heinsch, R. R. Nemani, and S. W. Running, "Improvements of the MODIS terrestrial gross and net primary production global dataset," Remote Sensing of Environment, (in press), 2004.

28. F. A. Heinsch, M. Reeves, P. Votava et al., "User's Guide, GPP and NPP (MOD17A2/A3) Products NASA MODIS Land Algorithm," http://www.ntsg.umt.edu/modis, 2003.

29. R. Kistler, E. Kalnay, W. Collins, S. Saha, G. White, J. Wollen, M. Chelliah, W. Ebisuzaki, M. Kanamitsu, V. Kousky, H. van den Dool, R. Jenne, and M. Fiorino, "The NCEP-NCAR 50-year reanalysis: Monthly means CDROM and Documentation," Bulletin of the American Meterological Society,. 82, 247-267, 2001.

30. M. C. Serreze, D. H. Bromwich, M. P. Clark, A. J. Ertringer, T. Zhang, and R. Lammers, "Large-scale hydroclimatology of the terrestrial Arctic drainage system," Journal of Geophysical Research, 107, 8160, doi:10.1029/2001JD00919, 2002.

31. Armstrong, R.L., K.W. Knowles, M.J. Brodzik and M.A. Hardman. 1994 - [2000-2002]. DMSP SSM/I Pathfinder daily EASE-Grid brightness temperatures. Boulder, CO: National Snow and Ice Data Center. Digital media and CD-ROM.

32. F. T. Ulaby, R. K. Moore, and A. K. Fung, Microwave Remote Sensing: Active and Passive, Vol 1, Artec House, Dedham, 1986.

33. J. F. Canny, "A computational approach to edge detection," IEEE Transactions on Pattern Analysis and Machine Intelligence, 8, 679-698, 1986.

34. W. Lucht, I. C. Prentice, R. B. Myneni, S. Sitch, P. Friedlingstein, W. Cramer, P. Bousquet, W. Buermann, and B. Smith B., "Climatic control of the high-latitude vegetation greening trend and Pinatubo effect," Science, 296, 1687-1689, 2002.

35. S. Frolking, K. C. McDonald, J. S. Kimball, J. B. Way, R. Zimmermann, and S. W. Running, "Using the spaceborne NASA scatterometer (NSCAT) to determine the frozen and thawed seasons of a boreal landscape," Journal of Geophysical Research, 104, 27,895-27,907, 1999.

36. IPCC, 2001: Climate Change 2001: The Scientific Basis, Contribution of Working Group I to the Third Assessment Report of the Intergovernmental Panel of Climate Change. J.T. Houghton, Y. Ding, D.J. Griggs, M. 
Noguer, P.J. vander Linden, X.Dai, K. Maskell, and C.A. Johnson (Eds.), Cambridge University Press, 881 pp. 2001.

37. T. Suni, F. Berninger, T. Markkanen, P. Keronen, Ü. Rannik, and T. Vesala, "Interannual variability and timing of growing-season $\mathrm{CO}_{2}$ exchange in a boreal forest," Journal of Geophysical Research, 108, 4265, doi:10.1029/2002JD002381, 2003.

38. J. S. Kimball, A. R. Keyser, S. W. Running, and S. S. Saatchi, "Regional assessment of boreal forest productivity using an ecological process model and remote sensing parameter maps," Tree Physiology, 20, 761-775, 2000. 